\title{
EchoGéo
}

23 | 2013

Entre l'ancien et le nouveau monde. La transcendance du lieu et de l'espace en géographie vinicole contemporaine

\section{Wines without Latitude: Global and local forces and the geography of the Thai wine industry}

Glenn Banks, Ratchaphong Klinsrisuk, Sittipong Dilokwanich et Polly Stupples

\section{OpenEdition \\ Journals}

Édition électronique

URL : https://journals.openedition.org/echogeo/13368

DOI : $10.4000 /$ echogeo. 13368

ISSN : 1963-1197

Éditeur

Pôle de recherche pour l'organisation et la diffusion de l'information géographique (CNRS UMR 8586)

Référence électronique

Glenn Banks, Ratchaphong Klinsrisuk, Sittipong Dilokwanich et Polly Stupples, « Wines without

Latitude: Global and local forces and the geography of the Thai wine industry », EchoGéo [En ligne], 23 |

2013, mis en ligne le 05 juin 2013, consulté le 10 août 2021. URL : http://journals.openedition.org/

echogeo/13368; DOI : https://doi.org/10.4000/echogeo.13368

Ce document a été généré automatiquement le 10 août 2021.

EchoGéo est mis à disposition selon les termes de la licence Creative Commons Attribution - Pas d'Utilisation Commerciale - Pas de Modification 4.0 International (CC BY-NC-ND) 


\title{
Wines without Latitude: Global and local forces and the geography of the Thai wine industry
}

\author{
Glenn Banks, Ratchaphong Klinsrisuk, Sittipong Dilokwanich et Polly \\ Stupples
}

\section{Introduction: Wine and Globalisation}

Quality grape wine can only be produced between 30 and 50 degrees of latitude, so the viticultural consensus has long been. In this zone the relatively large (especially in 'cooler-climate' zones) diurnal temperature range is optimal to produce the combination of sugar and acid levels that enable grapes to be turned into quality wine. As a result, within this temperate zone are located both the traditional 'old world' producers (France, Italy, Spain) and the major 'new world' wine producers including United States, Australia, South Africa and Argentina. The last three decades have witnessed a major shift, within the context of overall rapid growth of global production, from the 'old world' to the 'new', both in terms of production and, importantly, consumption (see table 1). This same period has seen the emergence (or re-emergence in some cases) of a range of other wine producers, what some have labelled the 'Third World' wine producers (Banks and Overton 2010). These countries, sitting largely within the tropics, push the expansion of viticulture and wine making beyond its traditionally conceived environmental limits. Examples include parts of tropical Africa, Latin America (Ecuador, Peru and Bolivia), the diverse locales of Tahiti, Hawaii and Bhutan, mainland South East Asia including Vietnam, Myanmar, and Cambodia (Johnson and Robinson 2009), and the focus of this paper, Thailand. 
Table 1 - Changing Patterns of Global wine production and consumption, 2000-2011

\begin{tabular}{|c|c|c|c|c|c|c|c|}
\hline \multicolumn{4}{|c|}{ Wine Production $(000 \mathrm{hl})$} & \multicolumn{4}{|c|}{ Wine Consumption (000 hl) } \\
\hline Country & 2000 & 2011 & $\begin{array}{l}\% \\
\text { change }\end{array}$ & Country & 2000 & 2011 & $\begin{array}{l}\% \\
\text { change }\end{array}$ \\
\hline France & 57,541 & 49,633 & -13.74 & France & 34,500 & 29,936 & -13.23 \\
\hline Italy & 51,620 & 41,580 & -19.45 & Italy & 30,800 & 23,052 & -25.16 \\
\hline Spain & 41,692 & 33,397 & -19.90 & Spain & 14,046 & 10,150 & -27.74 \\
\hline \multirow[t]{2}{*}{ Germany } & 9,852 & 9,611 & -2.45 & Germany & 20,150 & 20,000 & -0.74 \\
\hline & 160,705 & 134,221 & -16.48 & & 99,496 & 83,138 & -16.44 \\
\hline $\begin{array}{l}\text { \% share of Top } \\
10\end{array}$ & 70.82 & 63.12 & & $\%$ share of Top 10 & 60.86 & 49.44 & \\
\hline China & 10,500 & 13,000 & 23.81 & China & 10,695 & 17,000 & 58.95 \\
\hline $\begin{array}{l}\text { \% share of Top } \\
10\end{array}$ & 4.63 & 6.11 & & $\%$ share of Top 10 & 6.54 & 10.11 & \\
\hline USA & 21,500 & 18,740 & -12.84 & USA & 21,200 & 28,500 & 34.43 \\
\hline Argentina & 12,537 & 15,473 & 23.42 & Argentina & 12,491 & 9,725 & -22.14 \\
\hline Australia & 8,064 & 11,090 & 37.52 & Romania & 5,215 & 5,350 & 2.59 \\
\hline Chile & 6,674 & 10,463 & 56.77 & Russia & 4,699 & 11,633 & 147.56 \\
\hline \multirow[t]{2}{*}{ South Africa } & 6,949 & 9,665 & 39.08 & United Kingdom & 9,696 & 12,800 & 32.01 \\
\hline & 55,724 & 65,431 & 17.42 & & 53,301 & 68,008 & 27.59 \\
\hline $\begin{array}{l}\text { \% share of Top } \\
10\end{array}$ & 24.56 & 30.77 & & \% share of Top 10 & 32.60 & 40.45 & \\
\hline Top 10 total & 226,929 & 212,652 & -6.29 & Top 10 total & 163,492 & 168,146 & 2.85 \\
\hline $\begin{array}{l}\text { Total Wine } \\
\text { Prod }\end{array}$ & 280,000 & 265,000 & -5.36 & $\begin{array}{ll}\text { Total wine } \\
\text { consumption }\end{array}$ & 225,665 & 244,306 & 8.26 \\
\hline $\begin{array}{l}\text { Top } 10 \text { as \% of } \\
\text { Total }\end{array}$ & 81.05 & 80.25 & & $\begin{array}{l}\text { Top } 10 \text { as \% of } \\
\text { Total }\end{array}$ & 72.45 & 68.83 & \\
\hline
\end{tabular}

\section{Source: OIV 2012.}

2 These tropical locations provide conditions where the temperature and rainfall regimes are such that the grapevine (vitas vinifera) does not experience a vegetative dormancy 
(Camargo et al, 2012), an environmental condition that is not regarded as conducive to quality wine grape production. While grape growing in these new locations presents challenging environmental conditions for growers and winemakers, of equal interest are the cultural and economic drivers and limits that sit behind the growth of the wine industry in what were previously regarded as 'developing countries'. And while recent work on globalisation can provide insights into the processes that sit behind wine production in these new 'frontiers' for wine, conceptualisation can also work the other way: as Overton et al (2012, p. 275) recently wrote it is "through the study of global/ local articulations in the wine sector, [that] we can gain critical insights into geographies of globalization more generally."

Recent work on the globalisation of the wine industry has highlighted complementary and often contradictory processes at work: of shifting patterns of both wine consumption and production, of the entrenchment of distinct local and regional wine identities, and of very different forms of local, national and global regulation and investment patterns in the industry (Banks and Overton, 2010; Overton et al, 2012). This paper explores a number of these themes in the context of the Thai wine industry. This industry is small - tiny in the context of global production, but easily the largest in South East Asia - but it encapsulates neatly many of the tensions and trends that underscore the changing geography of the global wine industry. The paper is based on fieldwork undertaken in May and December 2012 by the first two authors that included interviews with, and field visits to, all nine of the Thai wineries, along with a review of secondary materials.

The paper begins with a historical overview of the development of the Thai industry, outlines its diverse geographic and economic nature, and then explores some of the tensions between local, national and global forces that both provide opportunities for Thai winemakers, and constrain the growth of the industry beyond its current limited extent.

\section{The Thai Wine Industry}

Wine grapes were first introduced to Thailand from France in the latter half of the 17th century,... along with half a dozen bottles of claret, as a gift to King Narai from Louis XIV of France (Metasit and Watchaneeporn, 2011; Stephens, 2007). Wine drinking, however, remained the reserve of the upper classes and grape wine-making ${ }^{1}$ did not emerge in Thailand until the latter half of the 20th century.

In the late 1950s two varieties of grape (Chenin Blanc and Syrah) were tested for their suitability to the Thai climate (Stephens, 2007). Apparently, the first plantings were conducted under the direction of the king, who initiated an early exploratory project into wine-making (Satrusayang, 2010). However, it was not until the 1980s and 1990s that Thai entrepreneurs began to establish dedicated vineyards and production facilities to process still wines. Thailand's largest grape wine producer, for example, Siam Winery, was founded in 1986 by the late Chalerm Yoovidhya (inventor and founder of the Red Bull energy drink). Initially focused on producing 'wine coolers', Siam entered still wine production in the 1990s. This burst of wine-making activity in Thailand in the 1980s and 1990s mirrors that of other 'new latitude' and 'new world' producers in Asia. Vineyard development in China and India, for example, also expanded rapidly at this time (Banks and Overton, 2010). 
7 Most of Thailand's nine current vineyards were established around this same time, although some (Silverlake and Shala One) are more recent. Thailand's vineyards are located across three geographic areas. In northern Thailand are Chateau de Loei and Shala One (in the north-eastern provinces of Loei and Phichit respectively) and Mae Chan Winery in the far north near Chiang Rai). In the Khao Yai area northeast of Bangkok are PB Valley Khao Yai, GranMonte, Village Farm and Alcidini. South of Bangkok lies Siam Winery in the Chao Phraya Delta (with its Hua Hin Hills Vineyard close to the beach resort of Hua Hin), and the Silverlake winery and vineyard near the beach resort of Pattaya (see illustration 1).

Illustration 1 - Thailand's wineries

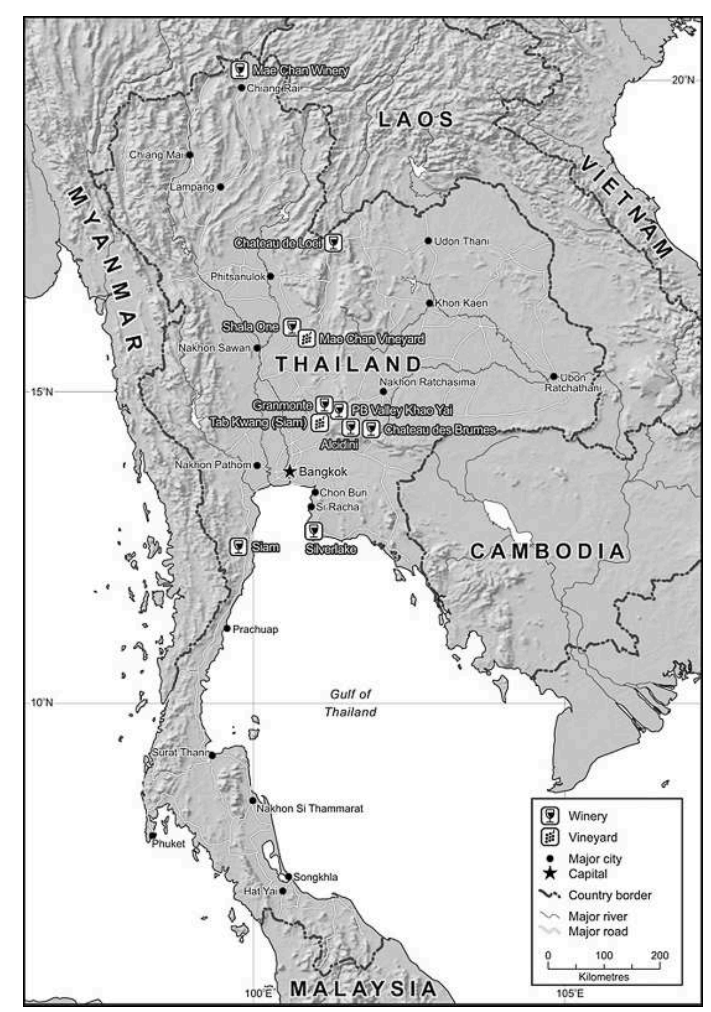

'Winery' indicates winery and vineyard: 'Vineyard' indicates just vineyard

Chateau de Loei, in the north, was the earliest vineyard to enter production in 1991 and the first to export Thai wine, starting in 1995. PB Valley Khao Yai winery was established in 1989 with the first harvest and production taking place in 1998-1999. Nearby GranMonte Estate began its vineyard operations in 1998 and launched its first wines in 2001. Village Farm/ Chateau des Brumes began its vineyard development in 1997 (see table 2).

Table 2 - Profiles of Thailand's nine wineries (Sources: Thai Wine Association data and interviews, May 2011)

\begin{tabular}{|l|l|l|l|l|l|l|l|}
\hline Wine & $\begin{array}{l}\text { Year of } \\
\text { first } \\
\text { Producer }\end{array}$ & $\begin{array}{l}\text { Area } \\
\text { under } \\
\text { vine } \\
\text { (ha) }\end{array}$ & Location & $\begin{array}{l}\text { Annual } \\
\text { Production } \\
\text { (bottles, } \\
\text { 2011) }\end{array}$ & $\begin{array}{l}\text { Exported } \\
\text { (\%) }\end{array}$ & $\begin{array}{l}\text { Ownership } \\
\text { type and } \\
\text { owner's } \\
\text { background }\end{array}$ & $\begin{array}{l}\text { Major } \\
\text { varieties }\end{array}$ \\
\hline
\end{tabular}




\begin{tabular}{|c|c|c|c|c|c|c|c|}
\hline GranMonte & 2003 & 12 & Khao Yai & 42,000 & 20 & $\begin{array}{l}\text { Family } \\
\text { Engineer }\end{array}$ & $\begin{array}{l}\text { Shiraz/ } \\
\text { Syrah, } \\
\text { Cabernet } \\
\text { Sauvignon, } \\
\text { Chenin Blanc }\end{array}$ \\
\hline $\begin{array}{l}\text { PB Khao } \\
\text { Yai winery }\end{array}$ & 1998 & 50 & Khao Yai & 118,000 & $15-20$ & $\begin{array}{l}\text { Private } \\
\text { industrialist: } \\
\text { brewery and } \\
\text { hospitality } \\
\text { industry }\end{array}$ & $\begin{array}{l}\text { Shiraz, } \\
\text { Tempranillo, } \\
\text { Chenin Blanc }\end{array}$ \\
\hline $\begin{array}{l}\text { Mae Chan } \\
\text { winery }\end{array}$ & 2005 & 16 & $\begin{array}{l}\text { Chiang } \\
\text { Rai, } \\
\text { Phetcha } \\
\text { Bun }\end{array}$ & $10-12,000$ & 0 & $\begin{array}{l}\text { Family - gem } \\
\text { trader }\end{array}$ & $\begin{array}{l}\text { Shiraz, } \\
\text { Dornfelder, } \\
\text { Tempranillo }\end{array}$ \\
\hline $\begin{array}{l}\text { Chateau de } \\
\text { Loei }\end{array}$ & 1995 & 64 & Loei & $4-500,000$ & 15 & $\begin{array}{l}\text { Private } \\
\text { industrialist: } \\
\text { construction }\end{array}$ & $\begin{array}{l}\text { Shiraz, } \\
\text { Chenin Blanc, } \\
\text { Cabernet } \\
\text { Sauvignon }\end{array}$ \\
\hline Alcidini & 2005 & 12 & Khao Yai & 15,000 & 0 & $\begin{array}{l}\text { Family } \quad- \\
\text { Engineer }\end{array}$ & $\begin{array}{l}\text { Shiraz, } \\
\text { Muscat }\end{array}$ \\
\hline $\begin{array}{l}\text { Chateau } \\
\text { des Brumes }\end{array}$ & 2002 & 40 & Khao Yai & 22,000 & 5 & $\begin{array}{l}\text { Family } \\
\text { industrialist: } \\
\text { petroleum } \\
\text { and refining }\end{array}$ & $\begin{array}{l}\text { Shiraz, } \\
\text { Cabernet } \\
\text { Sauvignon, } \\
\text { Chenin Blanc }\end{array}$ \\
\hline $\begin{array}{l}\text { Siam } \\
\text { Winery }\end{array}$ & 2003 & 45 & $\begin{array}{l}\text { Hua Hin } \\
\text { Hills, } \\
\text { Khao Yai }\end{array}$ & 263,800 & 65 & $\begin{array}{l}\text { Private } \\
\text { industrialist: } \\
\text { Red Bull } \\
\text { energy drinks }\end{array}$ & $\begin{array}{l}\text { Colombard, } \\
\text { Chenin Blanc, } \\
\text { Shiraz, } \\
\text { Tempranillo }\end{array}$ \\
\hline Silverlake & 2005 & 30 & Pattaya & 13,000 & 0 & $\begin{array}{l}\text { Family } \\
\text { shipping } \\
\text { company } \\
\text { owner }\end{array}$ & $\begin{array}{l}\text { Shiraz, } \\
\text { Chenin Blanc }\end{array}$ \\
\hline Shala One & 2008 & 30 & Phichit & & 0 & $\begin{array}{l}\text { Family } \\
\text { politics and } \\
\text { military }\end{array}$ & $\begin{array}{l}\text { Shiraz, } \\
\text { Cabernet } \\
\text { Sauvignon, } \\
\text { Tempranillo }\end{array}$ \\
\hline
\end{tabular}

Sources: Thai Wine Association data and interviews, May 2011.

9 The environments for wine production vary between sites: they range in elevation from approximately 75 meters above sea level at Silverlake and Shala One, to 550 meters at Alcidini, $400 \mathrm{~m}$ at Village Farm and $600 \mathrm{~m}$ at Chateau de Loei. Rainfall also varies somewhat across different sites, matching the shifting patterns of monsoonal rains across the country and various micro-climatic influences: at Chateau Mae Chan in the 
hill country in the far north mist can elevate moisture and humidity levels can persist for up to six months of the year, while in Khao Yai and the south unseasonal heavy rainfall and wind can damage buds during fruiting, dramatically affecting yields.

Vineyards were developed in these various sites for a range of reasons - some (such as Alcidini) were established by the owner after the purchase of land for non-vineyard reasons (in that case, for a country retreat). Others were more planned, with Siam, for example, putting considerable research into its selection of the Hua Huin Hills site. PB Khao Yai, GranMonte and Chateau des Brumes were chosen in part due to the elevation, and also for their proximity to Bangkok. Chateau de Loei resulted from an extensive search for a higher elevation, less humid site. Commins et al (2012, p. 86) provide a map of the climatic regions of Thailand that indicates that the existing vineyards are generally located within the less humid climatic zones, but they also note the important influence of micro-climates on grape-growing potential.

Given its relative recency, the Thai wine industry is still in a phase of experimentation and development. As Siam's winemaker Kathrin Puff explains in the winery's promotional literature 'even after 25 years, we are still in the experimental phase and developing the character of Thai wine'. New viticultural areas are still being established. In 2004 Siam Winery, for example, developed a new vineyard near the coastal resort of Hua Hin at the site of an old elephant corral. Established vineyards continue to extend their infrastructure and facilities, both for wine-making and for wine tourism. In 2009, GranMonte opened its new Asoke Valley Winery with a capacity to produce 120,000 bottles per annum and a guest house has recently been added to the estate's complex. New wine styles are continually being trialled with GranMonte for example, in 2011/2012 developing its first sparkling wines.

Experimentation is also evident in the variety of viticultural practices practised: different trellising systems, new and novel varieties (all major vineyards have separate trial areas where new varietals are tested to see how they respond to the local conditions) and varied responses to the abundant growth that the environment encourages. Two crops a year are possible at all sites: recent practice (following Indian industry methods) has been to prune twice a year but harvest only once in order to improve quality at the expense of quantity. However, wineries are continuing to innovate with this potential. At one site, for example, the possibility of harvesting one crop for wine production and one for grape juice is being tried. GranMonte now produces matching wines from different sides of the same vine (encouraged by selective leaf-plucking), an earlier picked wine from the sunnier side of the row and a wine from the later picked grapes grown on the more shaded side of the rows.

Thailand's wine producers vary in location but also in scale and focus. They range from smaller operations where wine-making may - initially anyway - be something of a hobby for the vineyards owners, to larger, more sophisticated operations that focus on quality, scale, innovation and export. Siam, PB Khao Yai and GranMonte are examples of the latter. One common feature in terms of the business model employed is the poor (in fact universally negative) returns generated by wine production alone: we were repeatedly told by participants across the industry that currently there was no profit to be made in Thai wine. This has forced all producers to link their production to other enterprises associated with wine tourism such as resorts, accommodation, and restaurants. For some that are part of larger business empires (PB Khao Yai, Chateau de Loei and Siam), the losses are absorbed by the larger business. In terms of quality, the 
wines produced vary from the forgettable to a selection of wines that compete successfully against global wines at international competition. GranMonte, for example, picked up 43 international awards for its wines in 2011, including two gold medals at the AWC Vienna International Wine Challenge, while PB Khao Yai picked up three medals at the same wine show in 2012, and Siam Winery regularly competes and is awarded medals at regional and prestigious international wine shows.

\section{Global influences, domestic development}

Wine production is very much a global industry and the Thai wine industry certainly bears a strong global imprint, although the local expressions of this vary dramatically in response to local expertise, regulation, culture and taste. It would be wrong, though, to conceive of the global influence as only working one way, with the external linkages also operating outwards from Thailand in terms of exports and growing linkages with other tropical wine producers.

All Thai wine-makers, of whatever scale, have developed their production with the assistance of European and/or Antipodean technology and expertise. Most use imported stainless-steel vats, some use French oak barrels or chips, and European staff or expertise is employed at many Thai vineyards. Siam's winemaker, Kathrin Puff, hails from Germany, for example, and Siam sends its staff regularly to France for training (Bell, 2007). Village Farm, and their Chateau des Brumes wines, are produced by a French wine-making team, and when their own season is poor, the vineyard actually utilises imported French Cabernet Sauvignon juice to blend with and bulk out their own production. Silverlake has done likewise with the same French network. Others draw on more specialised expertise with, for example, the internationally renowned $\mathrm{Dr}$ Richard Smart providing expert viticultural advice at a number of the Khao Yai operations from time to time (Smart, 2012).

Thai wine-making expertise is building, however. Nikki Lohitnavy of GranMonte is Thailand's first overseas-trained oenologist, graduating from the University of Adelaide with an Honours degree in viticulture and with work experience at vineyards in Portugal, South Africa, France and Australia. The Lohitnavy family that run GranMonte are intent on proving that quality wine can be made in Thailand by Thai wine professionals using Thai-grown grapes. Likewise at Chateau de Loei, Mae Chan, Siam, Shala One and PB Khao Yai, there are current winemakers or viticulturalists that have trained under French or German winemakers (both in Thailand and/or Europe) for a number of years, but are now confident enough to manage the vineyards or wine production (or both) themselves.

Thai wine producers are also actively involved in the building of regional and global expertise in tropical wine production. In November 2011 Chiang Mai hosted the $3^{\text {rd }}$ International Symposium on Tropical Wine, the seven day event involving 50 presentations with speakers and participants drawn from a broad sweep of tropical and temperate wine-producing countries including neighbouring Myanmar and Vietnam, France, Germany, Australia, New Zealand, South Africa, Brazil, India and Thailand (see subsequent papers by Commins et al, 2012; Raynal and Salai, 2012; Smart, 2012, and Camargo et al, 2012).

The external trade environment, and especially trade liberalisation in the region, provides a mix of greater opportunities and constraints to the emerging industry. 
While an increase in free trade agreements appears to correlate with the rise of wine consumption in Asia generally as wine becomes more affordable (Lee, 2009), it creates additional challenges for local Asian producers. Thai wine producers have been affected by the ASEAN Free Trade Agreement (AFTA), implemented in 2010, which reduced the import duty and excise tax on imported wine from other ASEAN countries from around $360 \%$ to $200 \%$ (Rungfapaisarn, 2010). A previous free trade agreement signed between Thailand, Australia and New Zealand, had already reduced the import duty on wine from $60 \%$ to about $20 \%$, and the duty will be eliminated completely by 2015 (Rungfapaisarn, 2010) ${ }^{3}$. Visooth Lohitnavy (GranMonte) is quoted as saying that 'AFTA will impact us severely, as our production costs are considerably higher than those for imported wines' (Rungfapaisarn, 2010). Most Thai wines, he argued, were available locally for between Bt400 and Bt700 a bottle but 'with AFTA, we will see some imported wines with prices of only Bt200 and Bt300 per bottle' (ibid.). Production costs in Thailand are high because of the need to use 'imported machines, tanks, equipment, barrels etc' (cited in Connell, 2012), and due to the costs associated with vineyard management, including the double pruning required over the course of a year.

The reduction of trade barriers is only likely to continue, however, as the wine market in Asia continues to grow. In September 2011, wine regulators from the 18 APEC governments met to share ideas on building the 'Pacific Rim Wine Trade' (Wine Institute, 2011). Over one-fifth of the global wine trade conducted by APEC members is conducted within the region and the volume of that trade has tripled over the last ten years to $\$ 3.6$ billion (ibid.). The APEC meeting discussed ways to reduce impediments to trade (including a focus on the role of the WTO and of the World Wine Trade Group or WWTG), as well as sharing 'best practices on wine certification, analysis, winemaking practices and labelling in the region' (ibid.). At this meeting, however, the Thai government delegation used the opportunity to promote a range of graphic health warning labels (discussed further below), indicating some of the political and cultural tensions that complicate this drive to grow the regional wine trade.

Thai wine producers regularly complain about the government's lack of support for this emergent industry, a factor which is seen to inhibit its growth. They often contrast their own situation with that of India, where the government is very supportive of the emerging wine industry, even helping to establish viticultural research centres:

The major obstacles facing the future growth of the wine industry in Thailand are taxes and security of tenure. To create a wine culture amongst the growing middle class in the country requires a minimum of offering an equivalent product at a cheaper price. This cannot be achieved under the existing government tax regime. History shows that close collaboration will be required between the privateacademic-government sectors to effect change.

(Commins, Asavasanti and Deloire, 2012, p. 94).

21 The difficulties of growing the domestic market (discussed below) have led producers not only to develop wine tourism ventures, but also to invest a lot of energy into expanding their export market. All of the medium sized Thai wineries (PB Khao Yao, GranMonte, Chateau des Brumes, Chateau de Loei and Siam) are involved in exporting their production. Siam is by far the largest exporter, exporting $60-70 \%$ of their wines annually to around 26 countries in Europe, North America and Asia (Siam Corporate Profile, p. 1), and being awarded the Prime Minister's Export Award in 2005 (ibid.).

Much of the export market is strategically directed towards Thai restaurants overseas. The United Kingdom is the largest importer of Thai wines, a fact attributable to its 
abundance of Thai restaurants (around 1200 Thai restaurants and more than 50 Thai pubs) (Jardine, 2003; Satrusayang, 2010). Thai vintners actively market their wine as particularly suitable for pairing with spicy Asian food and 'Thai wine for Thai food' has become a common marketing motto (Borg, n.d.). This is regarded as an initial niche position while the industry develops its quality. Kim Wachtveitl (Director of Business Development at Siam Winery) explains: 'It's a good approach for branding. It's a new product that consumers need to associate with Thailand and spicy food - and that is why the bulk of the current sales are in Thai restaurants outside Thailand. Later, the product will achieve an independent reputation' (cited in Borg, n.d.). Winemakers see considerable potential for growth through expanding exports to the approximately 10 , 000 Thai restaurants worldwide.

When Siam launched its Monsoon Valley wines in the UK, it targeted Thai restaurants, aiming to become 'the house wine of restaurants and pubs that serve Thai food' (Jardine, 2003). Siam has also launched its wines in Paris as part of a 'spicy food campaign' targeting Asian restaurants (Korean, Thai, Japanese, Indian and Chinese) in France (Anon, 2007). The winery has opened a London office and a European sales and marketing director to grow its export business in Europe (Jardine, 2003).

Although there is a focus on exporting wine to Europe for use in Thai restaurants, Thai winemakers are also looking to the Asian market, particularly China. While wine consumption in the traditional 'old World' appears to be falling (see table 1), wine consumption in Asia is rising rapidly, particularly in Hong Kong, Korea, Malaysia and Singapore. In China it has increased by sixty percent in the last decade (table 1). Overton, Banks and Murray point out that China now 'consumes as much wine as the United Kingdom' and is the sixth largest wine producer after France, Spain, Italy, the United States and Australia (2012, p. 275; see also table 1).

Lee (2009) describes the recent rapid growth in wine consumption in Asia as a symbol of globalization and notes that ' $\mathrm{t}] \mathrm{the}$ alcoholic beverage industry is one of the fastest globalizing industries' (p.259). Lee goes on to cite the fairly recent rise in wine consumption in Asia as due to 'its image as a healthy alcoholic beverage, and due to Asian consumers' preference for the Western lifestyle' (ibid., p. 260), also noting that the lower price of wine produced in bulk in places like the USA and Australia helps to make it more affordable and therefore appealing. Lee cites Bang and Cho, 2001 as arguing that "when Koreans learned from a variety of media such as TV news and newspapers that moderate red wine drinking can reduce heart disease, an increasing number of Korean consumers started drinking red wine'.

\section{Domestic drivers and challenges}

These global influences and connections, while critical in driving much of the growth and development of the industry, are shaped by sets of domestic factors, reflecting internal constraints and changes within Thai society. The extension of the wine industry into Thailand is, then, not a simple adoption or process of mimicry. Innovations in viticulture and winemaking were noted above, but it is also clear that 'cultures of consumption', sources of capital and tensions around the regulation of the Thai wine industry reflect domestic rather than international trends. Two such broad arenas are discussed below: cultural influences on both production and consumption, and the configuration of actors and forces involved in regulating the industry. 
In terms of domestic wine consumption, there is evidence of a growing wine culture in Thailand. Wine is enjoyed by a growing middle class of urban, educated and usually well-travelled young Thais. A study by New Zealand Trade and Enterprise (2011) noted that Thailand is experiencing increased urbanisation (with urban-dwelling Thais making up 33\% of the population) and a changing demographic:

... rising disposable incomes and a trend towards reduced time for food preparation at home is increasing demand for pre-packaged and convenience foods. Furthermore, overseas studies, international travel and the internet have led to an increasingly westernised younger population, who are open to new food tastes and are increasing the demand for imported food products.

(NZTE, 2011, p. 4)

Charters documents wine's long cultural association with status, and argues that today wine still signals both wealth (what kind of wine one is able to afford) and sophistication (how much one knows about wine) as a means of establishing social distinction (2006, p. 172). The adoption of a wine culture in Thailand also signals worldliness and familiarity with Western culture. Similarly, Banks and Overton argue that rapid economic growth in Asia (and in Eastern Europe) has driven new consumer demands and that 'to a large extent, the products that are demanded are icons of Western consumerism, whether luxury German cars, designer-labelled clothing or Bordeaux wines' (2010, p. 63).

Certainly Bangkok's burgeoning wine culture is evident in the number of new wine bars and restaurants opening in the city, although most of these offer imported wines rather than locally-produced vintages. Indeed this is a point of contention among the Thai wine producers. Unfortunately for Thai producers, part of wine's allure within the domestic market is precisely its foreign-ness, and status may be associated with a knowledge of French and Italian, rather than Thai, wines. This 'reverse parochialism' is also evident in the complaints of knowledgeable Thai wine drinkers that Thai wines were of an inferior quality to similarly priced French wines.

The culture of consumption extends beyond the bottle into the landscapes and experiences that are typically associated with wine. The association of wine in Thailand with status, sophistication, wealth and worldliness is visibly obvious in the estates themselves, most of which include grand and evocative buildings, French, Italian, Thai or 'fusion' restaurants, luxurious guesthouses and/or health spas, and carefully cultivated landscapes (see illustrations 2,3). The names of the vineyards frequently reinscribe the cultural attachment to Europe (GranMonte, Chateau des Brumes, Chateau de Loei) and wine events often feature jazz or classical European music (such as the 'delightful concertos of Antonio Vivaldi' offered at Silverlake's harvest festival in 2011). 
Illustration 2 - Wine landscape, GranMonte

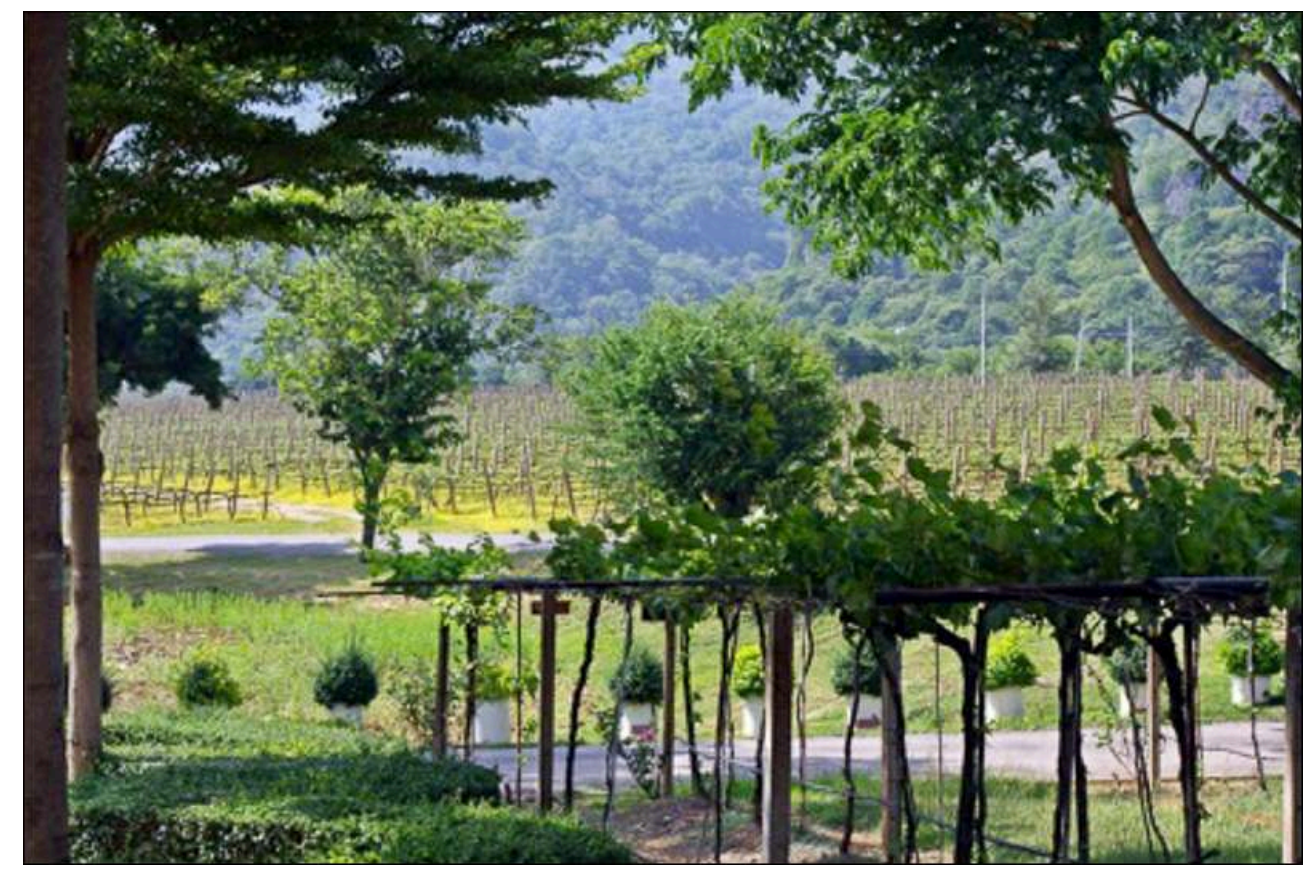

Author: G. Banks, 2012.

Illustration 3 - Winery entrance, Silverlake

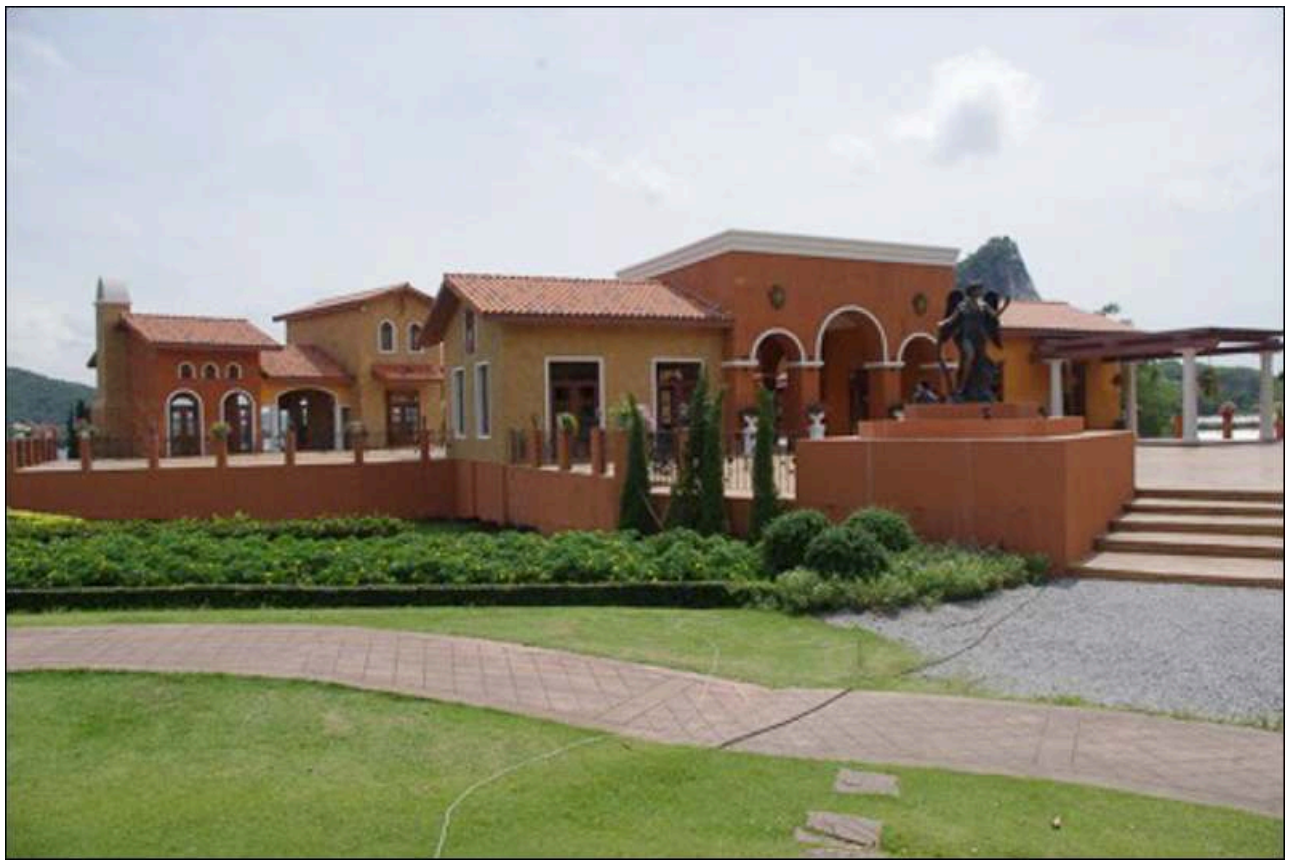

Author: G. Banks, 2012.

31 Such developments cannot be seen simply as the homogenising effects of globalisation however. Again, differentiation and localisation are also evident. Vineyards attract visitors through their associations with Western culture, but they also attract visitors through localised experiences such as elephant tours through the vineyards (offered by Siam at Hua Hin Hills, see illustration 4) or the unique experience of visiting Siam's 
floating vineyards, where the grapes (now used for wine cooler production) are grown on raised beds interspersed with canals. And while Vivaldi might be offered at a harvest festival, so too are the romantic strains of Thai artists B-Peeraphat and Sumeth.

Illustration 4: Elephants in the vineyard: Hua Hin Hills Winery

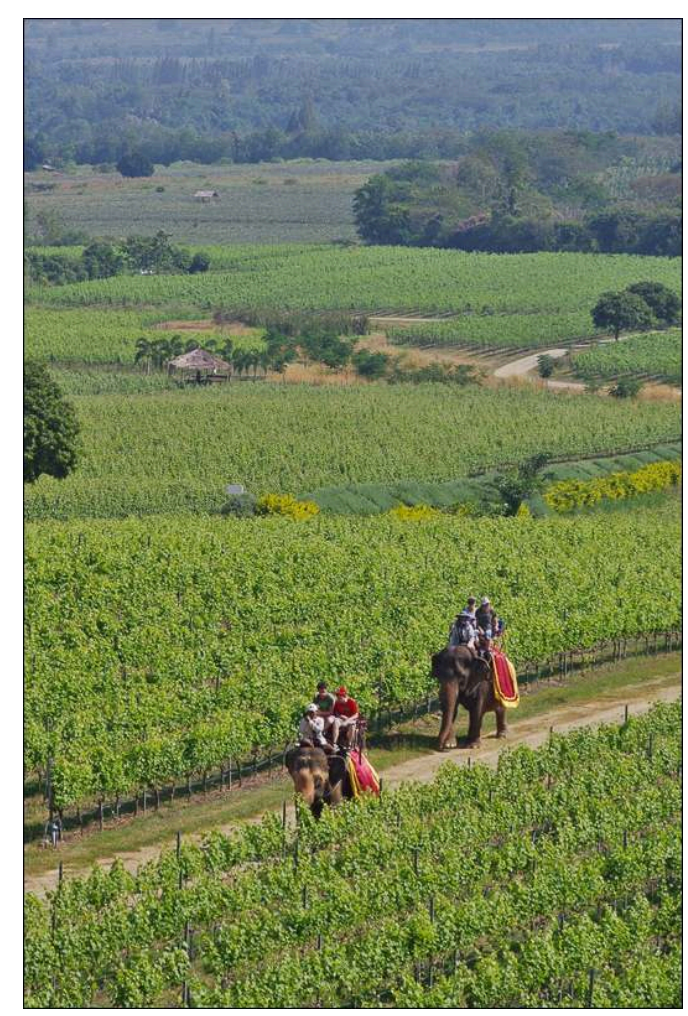

Author: G. Banks, 2012.

Status can be attributed not only to the wine drinker, but also to the wine producer and this is an important influence in terms of the source of capital within the Thai wine industry. Much of the literature on globalisation, and indeed many of the models for economic growth in developing economies, assumes that capital for growth is exogenous: that is, foreign direct investment provides the impetus for the development of new industries and, subsequently, growth. In the case of the global wine industry, this view has been contested (Overton et al., 2012) with specific forms of domestic investment seen as driving much of the growth in newly emerging wine areas.

In particular, Overton and Banks (2012) argue that there is symbolic or cultural capital attached to involvement in the wine industry that attracts local forms of investment in the industry, what they refer to as 'conspicuous production'. They define conspicuous production as 'investment in a productive enterprise without a primary interest in maximising profits from this investment; is highly visible; and primarily seeks to confer status or utility value on an individual, corporation or even the state carrying out the activity' (2012). Here the focus is on those Thai investors who become involved in the wine industry not for any financial returns but because of the cultural cachet that derives from the perceived prestigious nature of the industry and its product. Indeed the negligible financial returns (even substantial losses) that most Thai wineries make indicate another set of other motivations for their grand investments into wine production. 
of the owners spoken to, the motivations for involvement in the industry varied, although all had sampled and enjoyed fine wines from other parts of the world. Siam's wine production (and to a similar extent it was the same with PB Khao Yai) fitted into a broader corporate beverage portfolio. With Shala One, Alcidini and Silverlake there was a greater sense of individual interest in wine - almost to the point of it being a hobby, albeit an expensive one.

Thai wine-makers may also enjoy being seen as refined and worldly entrepreneurs, demonstrating technical mastery to produce a global product that can compete internationally. Indeed some actively promote Thai wine as an example of Thailand's technical sophistication and of the kind of value-added product that Thailand should be producing as an advanced economy. GranMonte, in particular, is known for its adoption of high-tech practices, including its use of a Smart Vineyard System, in which data about the vineyards, and decisions about their management, can be accessed and made from anywhere in the world.

In terms of the domestic regulation of the Thai wine industry, two elements are obvious: a strong commitment by most in the industry to self-regulation, and an antagonistic relationship between industry and government on a number of fronts. In terms of the former, a desire to establish Thailand as a producer of quality still wines from boutique vineyards lies behind the establishment of the Thai Wine Association (TWA), a self-regulating body that sets Thailand apart from many 'new latitude' producers. Formed in 2004, the TWA aims to 'set a standard and barometer for Thai Wines' (Satrusayang, 2010). Six out of Thailand's nine wine producers are currently members and these producers form a close-knit 'cluster' of friends as well as industry collaborators. The association members carry out and report on testing to ensure that minimum wine production and labelling standards regarding grape provenance, variety SO2 levels, volatile acidity levels and alcohol content labelling are met by its members (Perotti-Brown, 2009). An annual trip is made by all members to each other's property to view processes, standards and share innovations. The association in the past has also promoted the production of quality wines made from local grapes, organised seminars on and independent tastings of Thai wines, promoted wine culture and wine tourism in Thailand at international marketing events, and lobbied and negotiated with the government to improve conditions for Thai wine producers.

37 The roles of promoter (of wine culture) and negotiator (with authorities) are important ones given some of the regulatory challenges facing wine growers in Thailand in terms of developing a domestic wine market and in terms of contested ideas about alcohol consumption in Thailand. Where wine producers seek to promote wine-drinking as part of 'the lifestyle of educated middle-class people' (Visooth Lohitnavy cited in Rungfapaisar, 2010), dominant religious traditions - be they Buddhist or Islamic promote abstinence from drinking, and while wine growers promote wine as a healthgiving, Thai authorities see alcohol consumption as a serious public health issue.

Despite religious edicts promoting abstinence, the consumption of alcohol is fairly widespread in Thailand: about $48 \%$ of men and about $13 \%$ of women drink (Assanangkornchai et al, 2010). The most common beverages are traditionally-brewed rice-based spirits which are high in alcohol, and beer. Overall alcohol consumption has increased significantly over the last 20 years (Bung-On, 2001) and it is now regarded by the Thai government as a 'major public health problem' with negative impacts on 'economic development and social well being' (ibid.). In response, the government has, 
over the last 10-15 years increased measures aimed at reducing alcohol consumption. In 2001 an autonomous state agency, Thaihealth was established, funded by taxes on tobacco and alcohol, to promote good health in Thailand, including educational and advertising campaigns against tobacco and alcohol consumption (World Health Organisation, 2011, p. 46). Other initiatives include reducing the legal opening hours of bars and clubs, raising the legal drinking age from 18 to 20 (in 2008) and more recently proposing a requirement that all alcoholic products sold within Thailand (both locallyproduced and imported) carry large graphic images warning of the perils (motor vehicle accidents, domestic violence, self-harm) of consuming alcohol ${ }^{4}$. In another show of the reluctance of the government to support the industry, a major 'Bangkok International Wine Fair' was cancelled at the last minute in late 2010 due a government back-down over the issuing of tax emption status for wines imported for the convention.

39 As a result of the government's concerns about alcohol, wine is taxed very highly in Thailand. While the specific details of the tax regime are extremely complex (even for those in the industry) locally produced wines face taxes of up to $200 \%$ by the time they reach the customer (Bell, 2007; Connell, 2012). Tax on imported wine used to be higher but as noted above this is changing for some producers under free trade agreements, further exasperating Thai producers. Some of the winemakers spoken to did note, though, that they believed much imported wine was not taxed at the appropriate level anyway due to lax enforcement of tariff regulations. The excessive taxation burden the industry believed they were under was regarded as a major constraint to broadening the appeal of local wine to the domestic market (see also Commins, 2012).

\section{Conclusions}

40 The Thai wine industry is currently at an embryonic stage. Financially the industry is still one in which returns are, effectively, non-existent as the environmental constraints on wine production can be extreme: production at Silverlake dropped from 16t of grapes in 2011 to $2 t$ in 2012 due to rain during flowering, for example, and in another case, all the vines at Mae Chan were lost in 2009 due to constant mist and rain for an extended period. In large part, however, these environmental challenges are being overcome through innovation and experimentation within the industry.

41 The initial establishment of the Thai wine industry in the 1980s and 1990s was due in large part to the expansion and spread of the global wine industry beyond its traditional core, with foreign technologies and expertise critical to the development of the vineyards and wineries, and more recently some world class wines. This internationalisation of the industry, though, is strongly mediated by the tensions and possibilities that exist within the local and regional context: the development of free trade agreements, government regulation, plus a range of domestic interests, actors, cultural positionings and consumer tastes also influence and shape this nascent industry.

Given the range of challenges (environmental and political) noted above and the poor returns from the industry, the future prospects for the Thai wine industry are not particularly bright. It is hard to see the industry expand significantly over the next decade, for while some producers are making very good internationally competitive wine, the scale of production is still very small and there is no apparent interest from 
either global or domestic large-scale capital to make a significant capital investment into an industry that is environmentally and financially marginal. Land prices in key areas such as Khao Yai and the lack of government support - indeed government and economic and political hostility towards it - are also factors that mean the mediumterm future of the industry is likely to remain one of small-scale though relatively high-profile, boutique producers whose operations are closely tied in to targeted exports, wine tourism and the growing middle class in Thailand.

\section{BIBLIOGRAPHIE}

Anderson K., Nelgen S., 2009. Global Wine Markets, 1961 to 2009: A Statistical Compendium. Adelaide: Wine Economics Research Centre Retrieved from http://www.adelaide.edu.au/wine-econ/ databases/GWM/

Anderson K., Nelgen S., 2011. Wine's Globalization: New Opportunities, New Challenges. Adelaide, University of Adelaide.

Anon, 2007. Thai wine, anyone? Things Asian, 2 January 2007. Retrieved from http:// www.thingsasian.com/stories-photos/20810

Assanangkornchai S., Sam-Angsri N., Rerngpongpan S., Lertnakorn A., 2010. Patterns of alcohol consumption in the Thai population: Results of the National Household Survey of 2007. Alcohol \& Alcoholism, 45(3), p. 278-285.

Banks, G., Overton, J., 2010. Old World, New World, Third World? Reconceptualising the Worlds of Wine. Journal of Wine Research, 21(1), p. 57-75.

Bell T., 2007. A Thai wine? Whatever floats your boat. The Telegraph, 2 August 2007. Retrieved from http://www.telegraph.co.uk/news/worldnews/1559273/A-Thai-wine-Whatever-floatsyour-boat.html

Borg V. P. (n.d.). Wines for Spicy Food. Retrieved from http://www.victorborg.com/html/thaiwine.html

Bung-On Ritthiphakdee, 2001. Alcohol consumption and control in Thailand. The GLOBE: GAPA Bangkok consultation: Alcohol in Asia(4).

Chomsri N., Grossmann M., Commins T., Srisamatthakarn P., 2012. Research and development plan for fruit wine production in Thailand using Makiang as a case study. Asian Journal of Food and Agro-Industry, 5(01), p. 39-44.

Camargo U., Mandelli F., Conceição M.A., Tonietto, J., 2012. Grapevine performance and production strategies in tropical climates. Asian Journal of Food and Agro-Industry, 5(04), p. 257-269.

Commins T., Asavasanti S., Deloire A., 2012. What is tropical wine and what defines it? Thailand as a case study. Asian Journal of Food and Agro-Industry, 5(02), p. 79-95.

Connell C., 2012. Making quality wine in the tropics, Marlborough Express, 12 July.

Jardine A., 2003. Monsoon Valley targets Thai restaurants. Marketing (00253650). 
Lawrence, J., 2012. 'Corruption and smuggling' damaging Thai import prospects. Decanter. Retrieved from Decanter.com website.

Lee K., 2009. Is a glass of Merlot the symbol of globalization?: An examination of the impacts of globalization on wine consumption in Asia. International Journal of Wine Business Research, 21(3).

Metasit M., Watchaneeporn S., 2011. Sustainability Management for Wine Production: A Case of Thailand. World Academy of Science, Engineering and Technology, 77.

New Zealand Trade and Enterprise, 2011. Thailand Food \& Beverage: Market Profile 2011. Wellington: NZ Trade and Enterprise.

Overton J., Banks G., 2012. Conspicuous Production: Capital, status and wine. Under review, Capital and Class.

Overton J., Banks G., Murray W. E., 2012. The Race to the Bottom of the Glass? Wine, Geography, and Globalization. Globalizations, 9(2), p. 273-287.

Raynal F., Salai U., 2012. Experience of Red Mountain Estate in producing tropical wine in Myanmar. Asian Journal of Food and Agro-Industry, 5(01), p. 1-10.

Reiss S., 2008. Thailand: Winemaking in the Tropics - PB Khao Yai Winery Wine Education.Com. Retrieved from http://blog.wineeducation.com/2008/11/thailand-winemaking-in-tropics-pbkhao.html

Rungfapaisarn K., 2010. Thai wine-makers less enamoured with AFTA than drinkers, The Nation. Satrusayang C., 2010. Raise a glass! Thai wines winning global respect. CNN GO. Retrieved from http://www.cnngo.com/bangkok/drink/finally-thai-wines-getting-global-respect-593234

Smart R., 2011. Canopy Management for Tropical Vineyards. Proceedings of the $3^{\text {rd }}$ International Symposium on Tropical Wine. Chiang Mai, Thailand, November 2011.

Stephens N., 2007. Red Bull and Wine? Bourdeaux Undiscovered Wineshop. Retrieved from http:// bordeaux-undiscovered.co.uk/blog/2007/04/red-bull-and-wine/

Tripathi M., 2011. The talent behind Thai wine, The Nation.

Wine Institute, 2011. Asia-Pacific Regulators Meet to Streamline Pacific Rim Wine Trade. WineInstitute.org. Retrieved from http://www.wineinstitute.org/resources/pressroom/09212011 World Health Organisation, 2011. Global status report on alcohol and health. Geneva, World Health Organisation.

\section{NOTES}

1. Fruit wine production has a much longer and commercially successful history in Thailand, although it also has faced its share of challenges (see Chomsri N. et al, 2012 and Commins T., Asavasanti S., Deloire A. 2012).

2. Apparently this was undertaken as part of a larger strategy to slowly accustom the Thai palate to the fermented taste of wines (Siam, 2012).

3. This situation may be common to many emerging wine producers in Asia. Lee (2009, p. 162) describes the effects of Korea's free trade agreement with Chile which increased Chilean wine sales in Korea by almost $300 \%$ within two years.

4. The highly graphic nature of these health warning requirements (suggested images include a man grabbing a woman by the hair and threatening her with his fist to indicate increased domestic violence from alcohol use) along with their suggested size (covering $30 \%$ of a bottle's 
surface area) has created heated debate at WTO meetings and strong protest from alcohol producers in many parts of the world (Barta and Passariello, 2010).

\section{RÉSUMÉS}

Sur le plan historique, la production de raisin de cuve était limitée aux latitudes tempérées, en grande partie entre 30 et 50 degrés au-dessus et au-dessous de l'Equateur. Cependant, on assiste depuis peu à sa fabrication dans les pays des régions tropicales. Cet article analyse le développement et les caractéristiques de l'industrie vinicole thaïe, la plus importante des pays de l'Asie du Sud-Est. En le rattachant aux débats sur la mondialisation économique et culturelle, il étudie les motivations et les origines des producteurs thaïs, les contraintes environnementales, les adaptations locales ainsi que les contraintes réglementaires et culturelles au développement de cette industrie, ses liens mondiaux et ses perspectives. Notre argument est qu'en dépit de sa de petite taille, l'industrie vinicole thaïe intègre nettement nombre des complexités de la mondialisation, démontrant ainsi la fusion des tendances culturelles mondiales, la croissance économique nationaliste, la nature de plus en plus globale des acteurs de l'industrie vinicole ainsi que les contraintes permanentes exercées par le processus de mondialisation sur l'ensemble de ces régimes politiques internes et réglementaires.

Wine grape production has historically been restricted to temperate latitudes - largely between 30 and 50 degrees above and below the equator. Recently, though, wine has started to be made in countries within tropical regions. This paper explores the development and features of the Thai wine industry, the largest of the SE Asian wine producers. Linking in to arguments concerning economic and cultural globalisation, the paper explores the motivations and origins of the Thai producers, the environmental constraints and local adaptations to these, the regulatory and cultural constraints to the development of the industry, its global connections and prospects for the industry. Our argument is that despite its small size, the Thai wine industry neatly encapsulates many of the complexities around globalisation, demonstrating the fusion of global cultural trends, nationalistic economic growth, the increasingly global character of wine industry participants, and the continuing constraints on all these global processes of domestic political and regulatory regimes.

\section{INDEX}

Thèmes : Sur le Champ - Sur le Terrain

\section{AUTEURS}

\section{GLENN BANKS}

Glenn Banks, G.A.Banks@massey.ac.nz, is Associate Professor, Development Studies, School of People, Environment and Planning, Massey University, Palmerston North, New Zealand. He recently published:

- Banks G., Kuir-Ayius D., Kombako D., Sagir B., 2013. Conceptualising mining impacts, livelihoods 
and corporate community development in Melanesia. Community Development Journal.

- Overton J., Murray W., Banks G., 2012. The race to the bottom of the glass? Wine, geography and globalisation. Globalizations, 9(2), p. 273-287.

- Banks G., Murray W., Overton J., Scheyvens R.,2012. Paddling on one side of the canoe? The global aid regime, regional imperatives and the role of maverick agency in New Zealand's aid regime, 1970-2010. Development Policy Review, 30(2), p. 169-186.

\section{RATCHAPHONG KLINSRISUK}

Ratchaphong Klinsrisuk, ratchaphong.kli@mahidol.ac.th, is Dr in Faculty of Environment and Resource Studies, Mahidol University, Bangkok, Thailand

\section{SITTIPONG DILOKWANICH}

Sittipong Dilokwanich, sittipong.dil@mahidol.ac.th, is Associate Professor, Faculty of Environment and Resource Studies, Mahidol University, Bangkok, Thailand. He recently published:

- Suberi B., Dilokwanich S., Pumijumnong N., 2010. Role of Lamjithang community forestry towards quality of life of the local people. Environment and Natural Resource Journal, 8(3), p. 10-22.

\section{POLLY STUPPLES}

Polly Stupples, P.T.Stupples@massey.ac.nz, is Dr of Development Studies, School of People, Environment and Planning, Massey University, Palmerston North, New Zealand. She recently published:

- Stupples, P., Forthcoming. Creative contributions: the role of the arts and the cultural sector in development. Progress in Development Studies.

- Stupples, P., 2012. Breaking the Frame: Art in International Development. PhD, Development Studies, Palmerston North, Massey University.

- Stupples P., 2007. Culture as resource: the arts as part of development assistance. Online Proceedings of 'Sustaining Culture' (2008), Annual Conference of the Cultural Studies Association of Australia (CSAA), UniSA, Adelaide. 